\title{
Profile of abortion in Chile, with extremely restrictive law
}

\author{
Ramiro Molina-Cartes $^{1 *}$, Temístocles Molina ${ }^{2}$, Ximena Carrasco $^{3}$, Pamela Eguiguren ${ }^{4}$ \\ ${ }^{1}$ School of Public Health, Department of Obstetrics and Gynaecology, Faculty of Medicine, University of Chile, Santiago, Chile \\ ${ }^{2}$ Centre for Reproductive Medicine and the Integral Development of the Adolescent Faculty of Medicine, University of Chile, Santi- \\ ago, Chile \\ ${ }^{3}$ Chilean Ministry of Health, Santiago, Chile \\ ${ }^{4}$ School of Public Health Faculty of Medicine, University of Chile, Santiago Chile \\ Email: ${ }^{*}$ rammolinar@gmail.com
}

Received 10 November 2013; revised 8 December 2013; accepted 16 December 2013

Copyright (C) 2013 Ramiro Molina-Cartes et al. This is an open access article distributed under the Creative Commons Attribution License, which permits unrestricted use, distribution, and reproduction in any medium, provided the original work is properly cited. In accordance of the Creative Commons Attribution License all Copyrights (C) 2013 are reserved for SCIRP and the owner of the intellectual property Ramiro Molina-Cartes et al. All Copyright (C 2013 are guarded by law and by SCIRP as a guardian

\section{ABSTRACT}

Chile, together with El Salvador, Malta and Nicaragua has the most restrictive abortion laws. In these countries there is very little information on pregnancies that end in abortions. An analysis is made of official information regarding hospital discharges for abortion in Chile between 2001 and 2010, classified according to age and according to the WHO ICD 10. The Chilean Ministry of Health's Statistics Office (DEIS) collected the data. In 334,485 hospital discharges for abortion, Ectopic Abortion (O00), the Hydatidiform Mole (O01) and Other Abnormal Products of Conception (O02) corresponded to $37.2 \%$ of hospital discharges. Spontaneous Abortion (O03) reached $15 \%$ and Non Specified Abortion (O06) reached $35.5 \%$ and most probably included complications of induced abortions. $77 \%$ of hospital discharges corresponded to women between 20 and 34 years of age. Adolescents correspond to $11 \%$ of hospital discharges. In the annual average of 33,500 hospital discharges, Other Abnormal Products of Conception (O02), Other Abortions (O05), and Non Specified Abortions (O05) contribute to $72.7 \%$ of hospital discharges. This is explained by incomplete diagnoses, by means of the omission of induced abortion as this would mean jail for the woman and legal red-tape for the health personnel involved. Maternal mortality has not fallen. Abortion Mortality and Fatality rates do not change. There is a discrepancy between the law and hospital discharge diagnoses for abortion. The antiabortion law remains unheeded and obeys an ideological bias that brings damage and abuse to Chilean women. The aim of this study is to gain better information from a country that does not

\footnotetext{
"Corresponding author.
}

allow abortion under any circumstance, and its usefulness to countries in similar situations, together with its negative consequences on woman's health and rights.

Keywords: Abortion Discharges, Abortion Law, Unlawful Abortion

\section{BACKGROUND}

Chile together with El Salvador, Malta and Nicaragua has the most restrictive abortion laws [1-4]. Therapeutic abortion or an interrupted pregnancy is not allowed even in cases of risk of death or serious complications of pregnancy on maternal health. There is no information available, on the total female population, on what hap- pens in these countries as with pregnancies that are terminated by abortion, as it is very difficult to explore clandestine abortion and the information available is biased [5].

The World Health Organization defines abortion as the interruption of pregnancy with adequate procedures prior to fetal viability. This definition makes no mention of the fact that the fetus is alive or dead [6]. From a legal point of view, it has been interpreted as the interruption of the natural pregnancy process which produces the death of the fetus or product of conception. But there is no explicit explanation of this issue in Chilean legislation, only medico-legal or forensic interpretations [7]. Each country has definitions that vary in time and reforms in the legislation make it difficult to compare. From the point of view of obstetrics and gynecology, there is a variety of criteria for classifying abortion, but the one which is most frequently used is the WHO International Classification of Diseases (ICD 10) which permits an analysis according to age, gender, occurrence, prevalence, 
evolution in time and comparison among countries. Abortion appears in Chapter XV, heading $\mathrm{O}$ and has 9 categories (00 - 08) and 9 sub-categories [8].

Since 1931, therapeutic abortion in Chile has been contained in article 119 of the Health Code. Its text was repealed in 1989, towards the end of the dictatorship, and currently reads as follows: "No action may be taken which has the objective of provoking an abortion" [1].

The aim of this study is to provide the best official information available on abortion in Chile, to analyze its scope, limitations and to make it available to help other countries in similar situations, together with its eventual consequences on Women's Health.

\section{METHOD}

Official information has been obtained from hospital discharges for abortion cases in all the establishments in the country between 2001 and 2010, classified according to WHO ICD 10 and according to age. The records of discharge causes of hospitalized patients cover the whole country. The Ministry of Health's Department of Statistics (DEIS) collects this information through a special software application developed and placed at the disposal of all public and private establishments. The source is the National Hospital Discharge Statistics (IIEH), which is compulsory in the country. Diagnoses are recorded by physicians upon the patient's discharge from hospital and kept in the corresponding medical record [9]. These records are processed by specialized personnel in each hospital, and are validated by the Statistics Departments of each region. The DEIS finally validates, analyses, consolidates and publishes the information. In the case of this study, the DEIS provided a special analysis of the data base of hospital discharges for abortion in Chile, classified into five year age groups between 2001 and 2010.

The information analyzed is expressed in simple tables. Simple percentages and rates have been used with information on women of fertile age, live infants born provided by DEIS and INE (National Statistics Institute) $[9,10]$. The linear correlation coefficient uses the Pearson and Lee model.

\section{RESULTS}

Table 1 shows total annual discharges and WHO ICD 10 composition according to causes, remains stable over the decade. In a total of 334,485 discharges in 10 years, the highest proportion is $10.5 \%$ (2002), and the lowest $9.5 \%$ (2010), a difference that is not statistically significant. Discharges for ectopic pregnancies (O00) remain steady with variations of less than $2 \%$. Hydatidiform Mole (O01) reached a maximum of $12.8 \%$ and a minimum of 8.5 . Other abnormal products of conception (O02) also maintain similar proportions, varying from 10.8 to $8.9 \%$, and corresponding to $37.2 \%$ of total discharges.

This group includes the interruption of embryonic development, Non hydatidiform Mole, retained abortion and other specified and unspecified abnormal products of conception. These are open categories that not always have histopathological studies to back them. Spontaneous abortion (O03) reaches 15\%, which could be overnumbered.

Medical Abortion (O04), which includes legal abortion and therapeutic abortion are not recorded, as established by the current legislation. Non Specified Abortion (O06) is the second most frequent, with $34.7 \%$. For the hospital discharge statistical staff, this category is invoked when reports contain insufficient information and therefore cannot be given a more specific classification. This category might possibly include complications caused by hemorrhages in illegal voluntary abortions. The last two categories Failure of Induced Abortion (O07) and Complications caused by Abortion, Ectopic Pregnancy and Hydatidiform Mole reach very low percentages.

Table 2 shows the age distribution of the total abortions recorded in the 10 -year records.

$41 \%$ of discharges correspond to women between 25 and 34 years of age, and $77 \%$ to women between 20 and 34 years of age. Adolescents corresponded to $11 \%$ of total hospital discharges.

Ectopic pregnancy increases with age until the age of 34. Mola pregnancies reach $1.7 \%$ in adolescents. The same proportions are maintained in the following fiveyear periods. Other abnormal products of conception increase progressively till the age of 34 and remain steady until age 39. Spontaneous abortion has a greater frequency than expected between ages 20 to 39. Other Abortions corresponds to $60 \%$ in the 20 to 34 year olds. Non Specified Abortion accumulates high rates of discharge at all ages. The last two rubrics (O07 and 008) show no great variations with age.

Table 3 shows abortion risks according to age and causes. Adolescents have been divided into two groups: under 14 years of age and 15 to 19 years of age, in order to compare the information on these two groups, of which there is very little. The risk of ectopic pregnancy increases progressively with age, coming to 27.3 per 1000 for women of over 40; nevertheless the risk is greater in the 10 to 14 year old age group than in 15 to 19 year olds. The rest shows the classical J curves described as fertility risks according to age. The criteria of this cause coding do not differ in the analysis of abortion risk per 1000 live births and by age groups.

The last column gives indication of interruption of abnormal pregnancies for reasons of health. described in all textbooks, as is the case of ectopic pregnancies, molar 
Table 1. Hospital discharges for abortion cases. Chile 2001-2010, by year and WHO ICD.

\begin{tabular}{|c|c|c|c|c|c|c|c|c|c|c|c|c|c|c|c|c|c|c|}
\hline ICD & \multicolumn{2}{|c|}{ O00 } & \multicolumn{2}{|c|}{$\mathrm{O} 01$} & \multicolumn{2}{|c|}{$\mathrm{O} 02$} & \multicolumn{2}{|c|}{$\mathrm{O} 03$} & \multicolumn{2}{|c|}{ O05 } & \multicolumn{2}{|c|}{ O06 } & \multicolumn{2}{|c|}{$\mathrm{O} 07$} & \multicolumn{2}{|c|}{ O08 } & \multicolumn{2}{|c|}{ Total } \\
\hline Year & $\mathrm{N}$ & $\%$ & $\mathrm{~N}$ & $\%$ & $\mathrm{~N}$ & $\%$ & $\mathrm{~N}$ & $\%$ & $\mathrm{~N}$ & $\%$ & $\mathrm{~N}$ & $\%$ & $\mathrm{~N}$ & $\%$ & $\mathrm{~N}$ & $\%$ & $\mathrm{~N}\left({ }^{*}\right)$ & $\%$ \\
\hline 2001 & 3460 & 9.8 & 226 & 8.5 & 11065 & 8.9 & 6364 & 12.5 & 314 & 11.5 & 12667 & 10.9 & 40 & 11.3 & 249 & 13.9 & 34.385 & 10.3 \\
\hline 2002 & 3694 & 10.4 & 280 & 10.5 & 11752 & 9.4 & 5527 & 10.9 & 282 & 10.4 & 13175 & 11.3 & 33 & 9.3 & 225 & 12.5 & 34.968 & 10.5 \\
\hline 2003 & 3490 & 9.9 & 341 & 12.8 & 11702 & 9.4 & 5272 & 10.4 & 252 & 9.3 & 12162 & 10.5 & 57 & 16.1 & 221 & 12.3 & 33.497 & 10.0 \\
\hline 2004 & 3265 & 9.2 & 262 & 9.9 & 12399 & 10.0 & 4800 & 9.4 & 309 & 11.3 & 12342 & 10.6 & 43 & 12.2 & 225 & 12.5 & 33.645 & 10.1 \\
\hline 2005 & 3370 & 9.5 & 262 & 9.9 & 12231 & 9.8 & 4934 & 9.7 & 310 & 11.4 & 11813 & 10.2 & 70 & 19.8 & 194 & 10.8 & 33.184 & 9.9 \\
\hline 2006 & 3573 & 10.1 & 235 & 8.8 & 12818 & 10.3 & 4698 & 9.2 & 234 & 8.6 & 11388 & 9.8 & 62 & 17.6 & 137 & 7.6 & 33.145 & 9.9 \\
\hline 2007 & 3371 & 9.5 & 234 & 8.8 & 12542 & 10.1 & 4804 & 9.5 & 235 & 8.6 & 11169 & 9.6 & 43 & 12.2 & 134 & 7.5 & 32.532 & 9.7 \\
\hline 2008 & 3543 & 10.0 & 260 & 9.8 & 13396 & 10.8 & 4780 & 9.4 & 222 & 8.1 & 11098 & 9.6 & 2 & 0.6 & 123 & 6.8 & 33.424 & 10.0 \\
\hline 2009 & 3927 & 11.1 & 303 & 11.4 & 13925 & 11.2 & 4827 & 9.5 & 242 & 8.9 & 10422 & 9.0 & 3 & 0.8 & 123 & 6.8 & 33.772 & 10.1 \\
\hline 2010 & 3702 & 10.5 & 255 & 9.6 & 12697 & 10.2 & 4818 & 9.5 & 324 & 11.9 & 9971 & 8.6 & 0 & 0.0 & 166 & 9.2 & 31.933 & 9.5 \\
\hline Total & 35395 & & 2658 & & 124527 & & 50824 & & 2724 & & 116207 & & 353 & & 1797 & & 334485 & \\
\hline Mean & 3540 & 100 & 266 & 100 & 12453 & 100 & 5082 & 100 & 272 & 100 & 11621 & 100 & 35 & 100 & 180 & 100 & 33449 & 100 \\
\hline$\%$ ICD & 10.6 & & 0.8 & & 37.1 & & 15.2 & & 0.8 & & 34.7 & & 0.1 & & 0.5 & & 100.0 & \\
\hline
\end{tabular}

O00: Ectopic pregnancy; O01: Hydatidiforme Mole; O02: Other abnormal products of conception; O03: Spontaneous abortion; O04: Medical Abortion; O05: Other Abortion; O06:Unspecified abortion; O07:Failed Attempted abortion; O08: Complications following abortion and ectopic pregnancy and molar pregnancy; (") Total female population in fertile age (10 - 49 years old: 4, 820, 387 in 2001 and 5, 206, 810 in 2010, increasing 7,42\%). Latin America and Caribbean population estimates and projections 1950 2050. 2004, Demographic Bulletin United Nation/CEPAL/ECLAC, Bulletin 73, [62].

Table 2. Abortion risk by age and ICD10 of WHO. Chile 2001-2010. Ratios by 1000 New Born.

\begin{tabular}{cccccccccccccccccccccc}
\hline ICD & \multicolumn{2}{c}{ O00 } & \multicolumn{2}{c}{ O01 } & \multicolumn{3}{c}{ O02 } & \multicolumn{3}{c}{ O03 } & \multicolumn{3}{c}{ O05 } & \multicolumn{3}{c}{ O06 } & \multicolumn{3}{c}{ O07 } & \multicolumn{3}{c}{ O08 } \\
\hline Age & $\mathrm{n}$ & $\%$ & $\mathrm{n}$ & $\%$ & $\mathrm{n}$ & $\%$ & $\mathrm{n}$ & $\%$ & $\mathrm{n}$ & $\%$ & $\mathrm{n}$ & $\%$ & $\mathrm{n}$ & $\%$ & $\mathrm{n}$ & $\%$ & $\mathrm{n}$ & $\%$ \\
$5-9$ & -- & & -- & & -- & & -- & & -- & & 1 & 0.0 & -- & & -- & & 1 & 0.0 \\
$10-14$ & 57 & 0.2 & 40 & 1.5 & 410 & 0.3 & 328 & 0.6 & 23 & 0.8 & 721 & 0.6 & 8 & 2.3 & 9 & 0.5 & 1596 & 0.5 \\
$15-19$ & 1685 & 4.8 & 432 & 16.3 & 10500 & 8.4 & 6632 & 13.0 & 410 & 15.1 & 15840 & 13.6 & 61 & 17.3 & 226 & 12.6 & 35786 & 10,7 \\
$20-24$ & 5139 & 14.5 & 486 & 18.3 & 18735 & 15.0 & 10221 & 20.1 & 580 & 21.3 & 23077 & 19.9 & 86 & 24.4 & 354 & 19.7 & 58678 & 17.5 \\
$25-29$ & 8828 & 24.9 & 509 & 19.1 & 24757 & 19.9 & 10010 & 19.7 & 531 & 19.5 & 22372 & 19.3 & 73 & 20.7 & 408 & 22.7 & 67488 & 20,2 \\
$30-34$ & 9943 & 28.1 & 425 & 16.0 & 27728 & 22.3 & 9320 & 18.3 & 491 & 18.0 & 21133 & 18.2 & 73 & 20.7 & 377 & 21.0 & 69490 & 20.8 \\
$35-39$ & 7404 & 20.9 & 329 & 12.4 & 26209 & 21.0 & 8522 & 16.8 & 438 & 16.1 & 19676 & 16.9 & 34 & 9.6 & 276 & 15.4 & 62888 & 18.8 \\
$40-44$ & 2091 & 5.9 & 235 & 8.8 & 14363 & 11.5 & 5060 & 10.0 & 224 & 8.2 & 11713 & 10.1 & 17 & 4.8 & 114 & 6.3 & 33817 & 10.1 \\
$45-54$ & 248 & 0.7 & 202 & 7.6 & 1825 & 1.5 & 731 & 1.4 & 27 & 1.0 & 1674 & 1.4 & 1 & 0.3 & 33 & 1.8 & 4841 & 1.4 \\
Total & 35395 & 100. & 2658 & 100. & 124527 & 100 & 50824 & 100 & 2724 & 100 & 116207 & 100 & 353 & 100 & 1797 & 100 & 334485 & 100 \\
\hline
\end{tabular}

O00: Ectopic pregnancy; O01: Hydatidiforme Mole; O02: Other abnormal products of conception; O03: Spontaneous abortion; O04: Medical Abortion; O05: Other Abortion; O06: Unspecified abortion; O07:Failed Attempted abortion; O08: Complications following abortion and ectopic pregnancy and molar pregnancy.

Table 3. Abortion risk by age and ICD10 of WHO. Chile 2001-2010. Ratios by 1000 New Born.

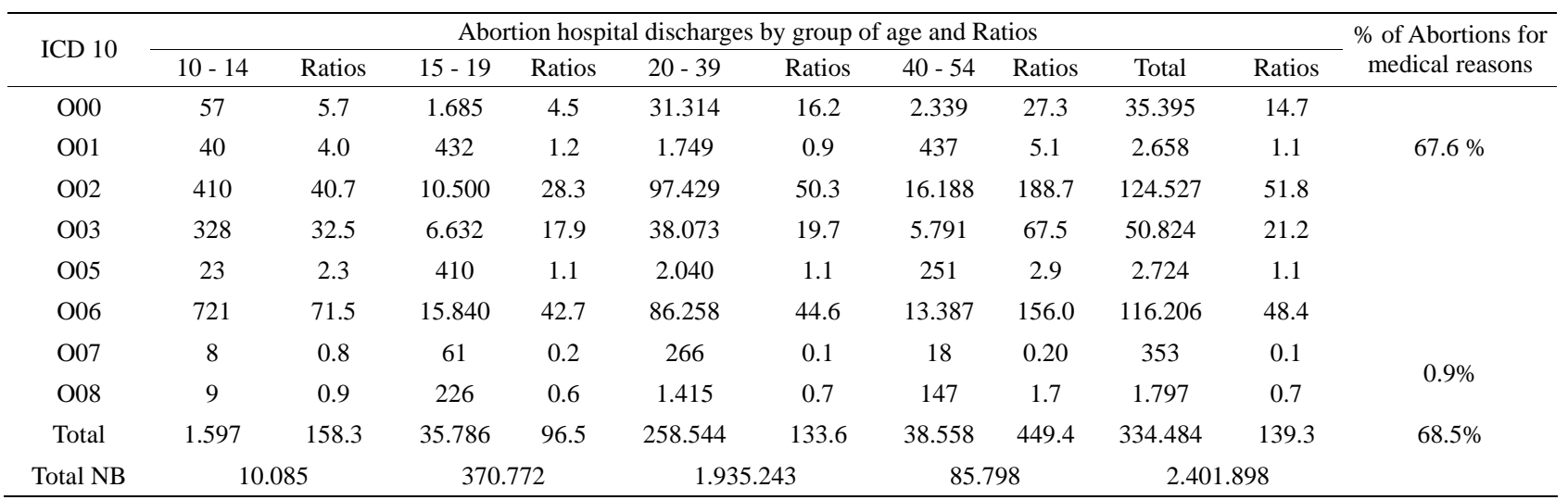

O00: Ectopic pregnancy; O01: Hydatidiforme Mole; O02: Other abnormal products of conception; O03: Spontaneous abortion; O04: Medical Abortion; O05: Other Abortion; O06: Unspecified abortion; O07: Failed Attempted abortion; O08: Complications following abortion and ectopic pregnancy and molar pregnancy. 
pregnancy and abnormal products of conception, which include undeveloped pregnancies, non hydatidiform moles, and other embryonic development abnormalities [11]. It adds failed abortion attempts and complications caused by ectopic pregnancies, moles, and other abnormalities of conception, which gives $68.5 \%$ of total hospital discharges.

An important proportion of abortions classified as having no specific cause could correspond to hemorrhagic complications of voluntary pharmacologically induced abortions.

Table 4 shows the abortion rate recorded in hospital discharges is high between the ages of 25 and 34. Lower rates are seen in women under19 years of age. This information depends on the age distribution of the Chilean population, with high rates in girls of under 19 years of age. It is indispensible to compare reasons for abortions with live births, as this is the best way of measuring pregnancy risk, when ending in abortion.

Table 5 gives the impact of abortion on maternal death and in abortion fatality.

Maternal death rate per 100,000 LB over the 10 year period reaches 2.4 and does not express a trend, varying from 1.2 in 2009 to 3.0 in 2005 and 2006.

Overall maternal death is 19.9 over the 10 year period, varying from 12.8 in 2003 to 20.8 in 2005, and has a not significant tendency to increase owing to Direct or Indirect Maternal Death.

Abortion fatality rate over the 10 year period is 15.5 deaths per every 100,000 hospital discharges for abortion, fluctuating from 8.9 in 2009 to 21.1 in 2005 and 2006. There is no definite trend in its development, but there are enormous variations from year to year.

\section{COMMENTS}

With an average of 33,500 annual hospital discharges for abortion,the most frequent causes are: Other Abnormal Products of Conception (O02) Other Abortions (O05) and Non Specified Abortions (O06), which correspond to $72.7 \%$. This leads us to suspect that this classification category has been overnumbered owing to incomplete diagnosis records on patients' discharge, where voluntary self induced abortions, or abortions caused by third parties, are omitted because in these cases the mother risks a jail sentence in addition to involving judicial red-tape for the health authorities. This is validated by a recent report of a qualitative research carried out by Universidad Diego Portales [12].

It is interesting to note that this classification does not show an important proportion of infectious or septic complications, which should be located in category (O08). This only reaches $0.5 \%$ and has tended to fall since 2001. This coincides with national data regarding the reduction of maternity ward beds destined to the treat- ment of septic complications of abortion [13].

The use of Misoprostol was introduced in Latin America 1984 for extremely specific medical use [14]. This prostaglandin is sold legally and illegally throughout the region and its emergence and use is associated to the fall in septic abortions throughout the Region [15].

Chile is no exception, and in spite of the fact that the drug is only available on a public and private institutional basis, the public can easily buy it through the internet and its sale also occurs in an informal parallel market which is unsafe, abusive, and even criminal because on many occasions false medications are given at very high prices that do not correspond the real market value of the product.

It is also interesting to see that although the market is easy to intervene, this has not occurred. The only explanation might be that the disappearance of this drug could result in the massive reappearance of abortion by means of abortions performed by non-qualified gynecologists, with the consequences known to us all [16]. Nevertheless, in order to ensure that there is no psychological pressure when obtaining data, the Chilean Ministry of Health has issued precise Guidelines to medical professionals on the use of Misoprostol in patients who request emergency treatment, or who are about to have an abortion, or have suffered the consequences of abortion [17].

Hospital discharges according to age show a profile similar to that described in various very old studies on abortion in Chile [18]. The larger proportion of hospital discharges for abortion in the categories, Other abnormal products of conception (O02) between the ages of 30 to 34 years and the items Other Abortions (O05) and Unspecified Abortions, with higher rates between the ages of 20 and 24, years leads us to suspect the existence of incomplete diagnoses at hospital discharge in the ages with a higher frequency of abortion. This confirms the

Table 4. Abortion rates by age. Chile 2001-2010 by 10,000 Female population.

\begin{tabular}{|c|c|c|c|}
\hline Age & $\begin{array}{c}\text { Female } \\
\text { population } \\
\text { At year } 2005\left(^{*}\right)\end{array}$ & $\begin{array}{c}\text { Mean of } \\
\text { abortions } \\
\text { in ten years( }\left(^{* *}\right)\end{array}$ & $\begin{array}{c}\text { Rates per } \\
10,000 \text { female } \\
\text { population }\end{array}$ \\
\hline $10-14$ & 731,237 & 160 & 2.2 \\
\hline $15-19$ & 719,637 & 3579 & 49.7 \\
\hline $20-24$ & 651,942 & 5868 & 90.0 \\
\hline $25-29$ & 580,621 & 6749 & 116.2 \\
\hline $30-34$ & 618,176 & 6949 & 112.4 \\
\hline $35-39$ & 620,390 & 6289 & 101.4 \\
\hline $40-44$ & 634,370 & 3382 & 53.3 \\
\hline $45-54$ & 987,607 & 474 & 4.8 \\
\hline Total & $5,543,980$ & 33,448 & 60.3 \\
\hline
\end{tabular}

( ${ }^{*}$ National Chilean Population. Information from Chilean National Institute Statitics. One case of abortion: 5 - 9 years old was not included. $\left(^{* *}\right)$ Annual mean Hospital abortion discharges (Total abortion in 10 years/10). 
Table 5. Maternal Mortality Rates by 100,000 NB and Fatality Abortion Rates. by 100,000 abortionhospital discharges. Chile 20012010 .

\begin{tabular}{|c|c|c|c|c|c|c|c|c|}
\hline \multirow{2}{*}{ Year } & $\mathrm{N}^{0}$ & \multicolumn{5}{|c|}{ MATERNAL MORTALITY } & \multirow{2}{*}{$\begin{array}{c}\text { NEW BORN } \\
\left({ }^{* *}\right)\end{array}$} & \multirow{2}{*}{$\begin{array}{l}\mathrm{N}^{0} \mathrm{Ab} \text {. Dischargesand } \\
\text { Fatality Rates }\end{array}$} \\
\hline & Rates $\left({ }^{*}\right)$ & O00-O08 ${ }^{\mathrm{a}}$ & $010-095^{b}$ & O96-O97 & O98-O99 ${ }^{\mathrm{d}}$ & Total & & \\
\hline \multirow[t]{2}{*}{2001} & $\mathrm{~N}^{0}$ & 4 & 29 & 1 & 11 & 45 & 246,116 & 34,385 \\
\hline & $\mathrm{MmR}$ & 1.6 & 16.7 & & & 18.3 & & 11.6 \\
\hline \multirow[t]{2}{*}{2002} & $\mathrm{~N}^{0}$ & 7 & 27 & 0 & 9 & 43 & 238,981 & 34,968 \\
\hline & $\mathrm{MmR}$ & 2.9 & 15.1 & & & 18.0 & & 20.0 \\
\hline \multirow[t]{2}{*}{2003} & $\mathrm{~N}^{0}$ & 5 & 18 & 0 & 7 & 30 & 234,486 & 33,497 \\
\hline & $\mathrm{MmR}$ & 2.1 & 10.7 & & & 12.8 & & 14.9 \\
\hline \multirow[t]{2}{*}{2004} & $\mathrm{~N}^{0}$ & 4 & 22 & 0 & 16 & 42 & 230,352 & 33,645 \\
\hline & $\mathrm{MmR}$ & 1.7 & 16.5 & & & 18.2 & & 11.9 \\
\hline \multirow[t]{2}{*}{2005} & $\mathrm{~N}^{0}$ & 7 & 21 & 3 & 17 & 48 & 230,831 & 33,184 \\
\hline & $\mathrm{MmR}$ & 3.0 & 17.8 & & & 20.8 & & 21.1 \\
\hline \multirow[t]{2}{*}{2006} & $\mathrm{~N}^{0}$ & 7 & 22 & 0 & 18 & 47 & 231,383 & 33,145 \\
\hline & $\mathrm{MmR}$ & 3.0 & 17.3 & & & 20.3 & & 21.1 \\
\hline \multirow[t]{2}{*}{2007} & $\mathrm{~N}^{0}$ & 4 & 26 & 2 & 12 & 44 & 240,569 & 32,532 \\
\hline & $\mathrm{MmR}$ & 1.7 & 16.6 & & & 18.3 & & 12.3 \\
\hline \multirow[t]{2}{*}{2008} & $\mathrm{~N}^{0}$ & 5 & 25 & 0 & 11 & 41 & 246,581 & 33,424 \\
\hline & $\mathrm{MmR}$ & 2.0 & 14.6 & & & 16.6 & & 15.0 \\
\hline \multirow[t]{2}{*}{2009} & $\mathrm{~N}^{0}$ & 3 & 28 & 0 & 19 & 50 & 252,240 & 33,772 \\
\hline & $\mathrm{MmR}$ & 1.2 & 18.6 & & & 19.8 & & 8.9 \\
\hline \multirow[t]{2}{*}{2010} & $\mathrm{~N}^{0}$ & 6 & 23 & 1 & 16 & 46 & 250,643 & 31,933 \\
\hline & $\mathrm{MmR}$ & 2.4 & 16.0 & & & 18.4 & & 18.8 \\
\hline C.C. & & 0.68 & 0.38 & 0.90 & 0.16 & 0.46 & & 0.90 \\
\hline \multirow{2}{*}{$\begin{array}{l}\text { Total } \\
10 y s .\end{array}$} & $\mathrm{N}^{0}$ & 60 & 264 & 10 & 148 & 482 & $2,195,182$ & 334.485 \\
\hline & $\mathrm{MmR}$ & 2.4 & 17.5 & & & 19.9 & & 15.5 \\
\hline
\end{tabular}

"Maternal Mortality Rate (MmR) per 100,000 NB (Report from Health Ministry). ${ }^{* *}$ Total Number of New Born per year (Report from Health Ministry). ${ }_{* * * *}^{*}$ Fatality Rate: Abortion death per 100,000 hospitalized abortion cases per year. ${ }^{\mathrm{a}}$ Abortion maternal Rates, ${ }^{\mathrm{b}}$ Direct maternal Rates ${ }^{\mathrm{c}}$ Late maternal Rates ${ }^{\mathrm{d}}$ Indirect Maternal Rates; ${ }^{\mathrm{C}}$ Linear Pearson Correlation Cofficient (n/s).

fact that in situations of extreme penalization of voluntary abortion, these figures are increased artificially. The same happens with spontaneous abortion at all ages between 20 and 34, which reaches proportions that are much higher than the expected 10 to $15 \%$ [19].

In the item Risk per Live Births, age distribution shows the classical evolution of fertility risk according to age [20]. Nevertheless the highest rates are seen in the categories other Abnormal Products of Conception and Non-specified Abortions, which reaffirm the doubt regarding an over-dimensioning of these categories that cover up non septic complications of voluntary pharmaceutically induced abortions

Molar pregnancy reaches its highest levels at both extremes of reproductive life, as has been seen in other publications, and reaffirms the fact that very early or late pregnancies tend to present genetic malformations in humans [20,21]

With regard to the expression of abortion risk for Women of Fertile Age, abortions accumulate in the intermediate reproductive age (25 - 39 years). When abortion is expressed according to Live Birth risk and ac- cording to age, the two highest rates appear in the categories, Other Abnormal Products of Conception (O02) and Unspecified Abortions (O06). This profile is explained as a consequence of the Chilean legislation that covers up real diagnoses, as has been explained above.

Another extremely important fact is the high frequency of medical recommendations on the part of the specialty of Obstetrics and Gynecology for the interrupttion of pregnancy owing to Ectopic Pregnancy, Molar Pregnancy and almost the totality of the category Other Abnormal Products of Conception [11]. To these headings it is necessary to add failed abortion attempts, which is a specialized medical action and the complications mentioned in the first three items of the ICD 10. All this comes to $68 \%$ of hospital discharges. It is impossible to give an exact estimate of how many abortions have been caused by reasons of health, and which have been included in the categories Other Abortion and Non-Specified Abortions. It is expected that in this profile 7 of every 10 hospital discharges correspond to interrupted pregnancies owing to reasons of health, which places Chilean law in a situation of contradiction, and makes it 
inapplicable, generating more risks than benefits and reveals the misinterpretation of a public policy based on laws that do not adjust to the reality of the normal evolution of human fertility and its consequences on maternal, fetal and perinatal morbidity

Chile has maintained one of the lowest maternal mortality rates in the Latin American Region, but this decade shows no great variations that indicate a falling trend. This occurs with Direct, Indirect and Total Maternal Mortality. It will possibly be necessary to implement additional measures in the areas of promotion and early detection of obstetric pathologies like hypertension, especially among youngsters of under 20 years of age inorder to change this rising trend. There is no change is specific abortion mortality.

The Abortion Fatality Rate per abortion varies amply with a tendency to remain as it is, which reflects the lack of impact of undesired pregnancy prevention measures or the non-application of a strategy aimed specifically at women with high Predictive Risks which had been successfully applied in the country [22]. For Chile, with extremely restrictive anti-abortion laws, it is impossible to gain more in-depth knowledge of what is really happening in the community. Furthermore, this restrictive law has no impact on the reduction of Maternal Mortality or on Abortion Fatality Rates.

Following the logic of a projection, this unchanged mortality should take into account the near-disappearance of septic complications which have been described as one of the great causes of maternal death by abortion. The CELADE (Latin American Centre for Demography) projection for Chile, based on an old study [23] calculated that for every woman hospitalized for abortion complications, there were 2 or 3 women in the community who aborted without complications, or who did not go to hospital, or whose complication was treated on an outpatient basis. Guttmacher has presented another series of projections for the countries of the Region [24], in which Chile has 3 women with illegal abortions who do not go to hospital for every hospital discharge for abortion.

This current profile of hospitaldischarges for abortion considers that the following categories should be taken as voluntary abortions: Other abortions (O05), Nonspecified abortions (O06), Failed abortion attempt (O07) with an annual average of 11,800 abortions to which it would be necessary to add $50 \%$ of hospital discharges for Other abnormal products of conception (O02): 6300 and $10 \%$ of hospital discharges for spontaneous abortions, which totals 18,200 hospital discharges per annum for induced abortion. With the introduction of Misoprostol, this figure should be multiplied by 6 , because it is estimated that for every hospital discharge for abortion, at least 6 women will have interrupted their pregnancy by means of abortion, without requiring hospital care.
This gives us an estimated total of 109,200 induced abortions per annum in the country. This figure could vary between 72,800 and 145,600.

\section{CONCLUSIONS}

The situation in Chile is characterized by a profile of Maternal and Perinatal Health with fewer risks than other developing countries, but with a tendency for an increase of Direct and Indirect Maternity Risks, and a stabilization in abortion deaths expressed as maternal mortality and abortion fatality. The current legal framework of extreme penalization and restriction of abortion have not given the expected results in the welfare of the population; it violates the fundamental human rights of women and exposes them to violence, abuse, discrimination, damage to their physical and mental integrity. Other studies show that in countries where abortion is legal, abortion rates fell as a consequence of the implementation of services which, together with providing the possibility of a safe abortion, give proper counseling services and offer access to methods for preventing new unwanted abortions [25].

In Chile, it has been shown that good quality contraception, including good quality service, and an ample availability of contraceptive methods prescribed by physicians and midwives, significantly prevent unwanted pregnancies in women with high predictive abortion risk [22]. These simple measures have not been applied.

The profile of hospital discharges for abortion in Chile shows a serious discrepancy between the abortion law and the daily practice of medicine in Health Services of the Public and Private Health Systems. Health professionals and workers are exposed daily to ethical conflicts, and tensions are created that contribute to hiding and giving misinformation on the grave problem of abortion and its consequences, seriously affecting reliable epidemiclogical information leading to making decisions on this issue.

This reality, which applies to various countries in the region, has received an international recommendation to "Consider the possibility of amending the laws regulations, strategies, and public policies on the voluntary interruption of pregnancy in order to protect the lives and health of women and adolescents, improving their quality of life and reducing the number of abortions" [26]. This study once again reaffirms the urgency with which our country must obey this recommendation.

\section{REFERENCES}

[1] Código de Derecho Sanitario Chileno. (1967) Artículo No. 119, 1989.

http://www.leychile.cl/Navegar?idNorma=5595

[2] Ley sobre el aborto Republica de El Salvador. (2012) http://abortolatinoamerica.com/aborto/legislacion/el-salva 
dor/

[3] Busuttil, C. (2005) Plans for abortion law to be entrenched in Constitution, Times of Malta.

http://www.wikigender.org/index.php/Abortion_in_Malta

[4] Supreme Court of Nicaragua. (2008) Challenge to Abortion Law in Nicaragua/Amici.

http://reproductiverights.org/en/case/challenge-to-abortio n-law-in-nicaragua-amici-supreme-court-of-nicaragua

[5] World Health Organization, Guttmacher Institute. (2012) Facts of induced abortion worldwide. Brief Fact Sheet. http://www.guttmacher.org/pubs/fb_IAW.html

[6] WHO. (1978) Induced abortion. Technical Report 623, Geneve.http://whqlibdoc.who.int/trs/WHO_TRS_623.pdf

[7] Carlos Künsemüller L. (2013) Delito de Aborto. Apuntes de derecho penal facultad de derecho. Universidad de Chile Departamento de Ciencias Penales. https://www.ucursos.cl/derecho/2008/2/D125A0634/3/ma terial_docente/objeto/196195

[8] WHO. (1994) International classification of diseases. Revision 10. http://www.who.int/classifications/icd/en/index.html

[9] Departamento de Estadísticas (DEIS). (2013) Ministerio de Salud de Chile. http://www.deis.cl/estadisticas-egresoshospitalarios/

[10] Instituto Nacional de Estadísticas de Chile (INE). (2013). http://www.ine.cl/canales/menu/publicaciones/calendario _de_publicaciones/pdf/completa_vitales_2011.pdf

[11] Beckmann, C., Ling, F.W., Herbert, W.N.P., Laube, D.W. Smith, R.P, Casanova, R., Chuang, A. Goepfert, A.R. Hueppchen, N.A. and Weiss, P.M. (2014) Ectopic Pregnancy and Molar Pregnancy. In: Horvath, K. andWilliams, L. Eds., Obstetrics and Gynecology (7th Edition), 179-185; 394-395. Lippincott Williams \& Wilkins, 351 West Camden Street Baltimore MD 21201, USA, Printed in China.

[12] Casas, L. and Vivaldi, L. (2013) La pelización del aborto como una violación a los derechos humanos de las mujeres. Informe Anual sobre Derechos Humanos en Chile, 2013. Universidad Diego Portales. Ediciones UDP. http://www.emol.com/noticias/nacional/2013/10/14/6245 01/informe-de-ddhh-de-la-udp-recomienda-despenalizarel-aborto-en-chile.html

[13] Molina, R.C. (2013) Aspectos bioéticos del aborto en Chile. 2nd Edition, Revista Chilean Obstetricia y Ginecologia, 78, 259-261.

http://www.revistasochog.cl/articulos/ver/645

[14] WHO. (2012) Safe abortion: Technical and policy guidance for health systems. 2nd Edition. Geneve. http://www.ncbi.nlm.nih.gov/books/NBK138196/

[15] (2013) Aborto en Latinoamérica. Información de aborto en Latinoamérica. El misoprostol es un método seguro para abortar en la clandestinidad.

http://lac.unfpa.org/webdav/site/lac/shared/IMAGES/201 1/PUBLICACIONES/misoprostolyabortoconmedlatinyca ribe.pdf

[16] Donoso, E. (200) ¿Unsafe Abortion in Chile? Revista Chilena de Obstetricia y Ginecología, 73, 359-361. http://www.scielo.cl/scielo.php?pid=S071775262008000 $\underline{600001 \& s c r i p t=s c i}$ arttext

[17] Ministerio de Salud. (2009) Ordinario A 15. 1675. Extracción de confesiones sobres conductas abortivas de pacientes mujeres.

http://www.icmer.org/documentos/salud_y_derechos_sex _y_rep/instruct_minsal_confidenc_y_aborto.pdf

[18] Ramiro Molina C. (1995) Aborto Inducido. In: Sánchez, G.A.P. (2nd Edition), Ed., Mediterráneo Santiago. Chile.

[19] Silva, S. (2011) Aborto 2011. In: Obstetricia. Editores Pérez Sánchez, Enrique Donoso. Cuarta Edición. Editorial Mediterráneo, Santiago.

[20] Committee on Maternal Nutrition/Food and Nutrition Board (1970) Biosocial and psycogical determinants of pregnancy outcome (16-20). Maternal nutrition and the course of pregnancy. National Academy Science. Washington DC.

http://onlinelibrary.wiley.com/doi/10.1002/tera.14200601 $\underline{11 / \text { abstract }}$

[21] Gamer, E.L., Goldstein, D.P., Felmate, C.M. and Berkowitz, R.S. (2007) Gestational trophoblastic disease. Clinical Obstetrics and Gynecology, 50, 112-122. http://dx.doi.org/10.1097/GRF.0b013e31802f17fc

[22] Molina, R., Pereda, C., Cumsille, F., Martinez Oliva, L., Miranda, E. and Molina, T. (1999). Prevention of pregnancy in high risk women: Community intervention in chile. Chapter 2 (57-77). In: Mundigo, A. and Indriso, C., Eds., Abortion in the Developing World, WHO, Vistaar Publication, London.

[23] Barbara Santee (1975). A prospective abortion study in Santiago, Chile. Scientific Publication. No 206. Pan American Health Organization.

[24] Rossier C. (2003) Estimating induced abortion rates: A review. Studies in Family Planning, 34, 87-102. http://apps.who.int/iris/bitstream/10665/75173/1/WHO_R HR_12.01_eng.pdf

[25] Sedgh, G., Singh, S., Shah, I.H., Ahman, E., Henshaw, S.K. and Bankole, A. (2012) Induced abortion: Incidence and trends worldwide from 1995 to 2008. Lancet, 379, 625-632.

[26] CEPAL. (2013) Consenso de Montevideo. Primera reunión de la conferencia regional sobre población y desarrollo de América Latina y el caribe. Page 14/42. http://www.acnur.org/t3/fileadmin/Documentos/BDL/201 3/9232.pdf?view=1 